\title{
Tingkat Kesepahaman Masalah terkait Obat antara Dokter dan Apoteker di Apotek
}

\author{
Fauna Herawati ${ }^{1}$, Ni Nyoman Yuni Astrini ${ }^{1}$, dan I Made Agus Gelgel Wirasuta ${ }^{2}$ \\ 1 Fakultas Farmasi Universitas Surabaya, Surabaya \\ 2 Jurusan Farmasi, Fakultas Matematika dan Ilmu Pengetahuan Alam, Universitas Udayana
}

Korespondensi: Fauna Herawati

Email:fauna@staff.ubaya.ac.id

\begin{abstract}
ABSTRAK: Kolaborasi antar tenaga kesehatan diperlukan untuk meningkatkan pelayanan kesehatan kepada pasien. Kolaborasi antar tenaga kesehatan didefinisikan sebagai profesional tenaga kesehatan dengan peran yang saling melengkapi dan kooperatif bekerja sama, berbagi tanggung jawab untuk pemecahan masalah dan pengambilan keputusan untuk merumuskan dan melaksanakan rencana perawatan pasien; demikian pula dalam kolaborasi dokter dan apoteker, diperlukan kesepahaman tentang masalah terkait obat. Penelitian ini bertujuan untuk mengukur tingkat kesepahaman dokter-apoteker di klinik pada periode September-Oktober 2013. Penelitian ini menggunakan metode deskriptif observasional dan dilakukan di salah satu apotek di Bali yang bekerja sama dengan dokter spesialis penyakit dalam. Sampel penelitian adalah resep dokter spesialis penyakit dalam untuk pasien diabetes mellitus (DM) dan pengambilan resep dilakukan secara consecutive sampling. Jumlah sampel yang berhasil diperoleh berjumlah 102 lembar resep pasien diabetes melitus rawat jalan yang akan dianalisis melalui 3 tahap dengan menggunakan elemen medication therapy management (MTM), daftar periksa the Pharmaceutical Care Network Europe (PCNE) versi 6.2, dan kappa agreement. Hasil analisis menunjukkan tingkat kesepahaman $(\kappa)$ sebesar 0,84. Kesepahaman antara dokter dan apoteker tentang masalah terkait obat sangat baik (95\% sepaham); ketidaksepahaman terutama terkait pertimbangan klinis penggunaan obat dan kepatuhan pasien, oleh karena itu apoteker perlu meningkatkan pengetahuan agar dapat berkontribusi dalam kolaborasi tersebut. Apoteker dalam kolaborasi interprofesional dapat berperan dalam pengaturan dosis, identifikasi efek samping, rekonsiliasi pengobatan, dan memberikan rekomendasi terapi berbasis bukti.
\end{abstract}

Kata kunci: tingkat kesepahaman; apotek; diabetes

\begin{abstract}
Collaboration between health care professionals is necessary to improve patient care. Collaboration in health care is defined as a cooperative and complementary roles between health care professionals to share responsibilities for problem-solving, and finally to generate decisions for the patient. There is should be an agreement about the drug-related problem to do a collaborative therapy management. The objective of this study is to measure the level of agreement between physician and pharmacist in community pharmacy setting. The study was conducted in a community pharmacy in Bali in collaboration with a specialist in internal medicine. In this study, prescriptions are consecutively collected from the pharmacy record. Identification of drug-related problems was conducted in 102 outpatient patients with diabetes mellitus. The analysis shows a strong association between physician and pharmacist decision about drug related problems with the kappa agreement $(\kappa)$ of 0.84 . Disagreement was mainly related with clinical aspects related to drug usage and patient adherence. Hence, it is recommended for the pharmacists to increase their knowledge in order to further contribute to the collaboration. Pharmacists in collaboration with other health care professionals may play a role in dosage adjustments, identification of medication side effects, medication reconciliation, and to provide evidence-based treatment recommendations.
\end{abstract}

Keywords: agreement; pharmacy; diabetes 


\section{Pendahuluan}

Menurut Peraturan Menteri Kesehatan Republik Indonesia Nomor 35 tahun 2014 tentang standar pelayanan kefarmasian di apotek menyatakan bahwa pelayanan kefarmasian di apotek terdiri dari: pengelolaan sediaan farmasi, alat kesehatan, dan bahan medis habis pakai; serta pelayanan farmasi klinik. Pada proses pelayanan farmasi klinik, apoteker wajib melakukan medication review, yaitu mengidentifikasi masalah terkait obat dan mengkomunikasikannya dengan pasien serta dokter agar tercapai hasil terapi yang optimal [1]. Kolaborasi apoteker, dokter, tenaga kesehatan lain, dan pasien diperlukan dalam pengambilan keputusan terapi obat untuk memaksimalkan kualitas hidup pasien dan mengurangi masalah terkait obat [2]. Penelitian Granas (2006) di Norwegia pada 71 medication review (73 pasien) yang dilakukan oleh 24 apoteker di 23 apotek melaporkan bahwa 98\% (52/53) pasien mendapat manfaat dan $81 \%$ pasien akan menerima tawaran medication review kembali; teridentifikasi 88 masalah terkait obat dari peresepan 43 pasien, tingkat kesepahaman identifikasi masalah terkait obat antara apoteker apotek dan tim evaluasi (seorang dokter spesialis penyakit dalam dan endokrinologi, 2 orang apoteker bangsal di rumah sakit, dan seorang apoteker apotek) adalah 0,87 [3].

Penelitian ini bertujuan untuk mengetahui tingkat kesepahaman antara apoteker dan dokter Spesialis Penyakit Dalam untuk penetapan masalah terkait obat diabetes mellitus (DM) di salah satu apotek di Bali. Data terkait tingkat kesepahaman di Bali masih belum diketahui dan tingkat kepuasan pasien saat berkunjung ke apotek di Bali bisa dibilang masih rendah. Penelitian tentang seberapa besar tingkat kesepahaman antara apoteker dan dokter perlu dilakukan karena semakin besar kesepahaman antara dokter dan apoteker, maka diharapkan dapat lebih meningkatkan outcome terapi yang dilakukan [3].

\section{Metode}

Penelitian ini menggunakan metode deskriptif observasional dan dilakukan di salah satu apotek di Bali yang bekerja sama dengan dokter spesialis penyakit dalam pada Periode September-Oktober 2013. Populasi yang digunakan adalah semua resep pasien diabetes mellitus yang menyerahkan resepnya di apotek. Sampel yang digunakan meliputi resep dari Dokter Spesialis Penyakit Dalam kepada pasien DM tipe 1 dan tipe 2 yang memeriksakan diri dan menyerahkan resepnya di apotek X. Kriteria inklusi dalam penelitian ini adalah semua resep pasien diabetes mellitus yang menyerahkan resepnya di apotek periode September-Oktober 2013; dan faktor eksklusinya adalah resep pasien rawat inap, salinan/kopi resep, dan resep yang dibawa bukan oleh pasien yang bersangkutan.

Resep pasien diabetes mellitus rawat jalan diskrining (skrining administratif, farmasetis dan pertimbangan klinis) dan dianalisis. Beberapa informasi yang ditanyakan kepada pasien adalah keluhan atau gejala yang dialami oleh pasien, hasil pemeriksaan tanda-tanda vital dan tes laboratorium yang dibawa oleh pasien, serta semua obat yang sedang dikonsumsi saat pengambilan data dilakukan. Masalah terkait obat diklasifikasikan menurut daftar periksa yang diterbitkan oleh Pharmaceutical Care Network Europe (PCNE); analisis dilakukan dengan membandingkannya dengan pedoman terapi dan jurnal-jurnal ilmiah terkait. Apoteker melakukan identifikasi masalah terkait obat dan mendiskusikannya dengan dokter penulis resep. Untuk mengukur tingkat kesepahaman digunakan Cohen's Kappa [4]. Tingkat kesepahaman dikelompokkan sebagai berikut: sangat baik $(0,8 \leq \kappa \leq 1)$, dapat diterima $(0,61 \leq \kappa$ $\leq 0,8)$, sedang $(0,41 \leq \kappa \leq 0,6)$, rendah $(0,21 \leq \kappa \leq$ $0,4)$, buruk $(0 \leq \kappa \leq 0,2)$, tidak ada kesepahaman $(\kappa<0)$. Oleh karena data penelitian menggunakan skala nominal, maka perhitungan dilakukan dengan metode non-parametrik chi-square. 


\section{Hasil}

Pada penelitian ini lebih dari $90 \%$ pasien berusia $\geq 40$ tahun, jumlah pasien laki-laki (57) lebih banyak daripada perempuan (45), dan lebih dari $50 \%$ memiliki penyakit penyerta kardiovaskular (Tabel 1).

Jumlah total obat yang diresepkan adalah 468 obat, yang terdiri atas $144(30,77 \%)$ obat generik dan $324(69,23 \%)$ obat non generik. Jenis atau golongan obat dan frekuensi penggunaannya dapat dilihat pada Tabel 2 .

Peresepan obat yang banyak ditemukan pada penelitian ini adalah obat antidiabetik (182 obat) dan antihipertensi (100 obat). Dari 182 obat antidiabetik yang diresepkan, ditemukan masalah terkait obat (MTO) pada 5 obat, sedangkan sisanya (177 obat antidiabetik yang diresepkan) tidak terdapat MTO. Pada obat antihipertensi, ditemukan 1 MTO dan 99 obat antihipertensi tidak terdapat MTO. Diagnosa pada pasien yaitu diabetes dan diabetes dengan komorbid. Pada resep pasien dengan diabetes (36 resep), MTO ditemukan pada 3 resep dan sisanya (33 resep) tidak terdapat MTO; sedangkan pada pasien diabetes dengan penyakit komorbid (66 resep), MTO ditemukan pada 20 resep dan sisanya (46 resep) tidak ditemukan MTO. Hasil penentuan masalah terkait obat oleh dokter-apoteker dapat dilihat pada Tabel 3.
Rasio dokter-apoteker sepaham $=(18+79) / 102=$ $97 / 102=0,95$

Kesepahaman yang diharapkan (expected agreement $)=$

$[(23 / 102) \times(18 / 102)]+[(84 / 102) \times(79 / 102)]=$ $0,04+0,64=0,68$

Kappa, $\kappa=(0,95-0,68) /(1-0,68)=0,27 / 0,32=$ 0,84 (sangat baik, $0,8 \leq \kappa \leq 1$ )

CI95\% $=0,84 \pm 1,96 \sqrt{[}[(0,84 \times 0,16) / 102)]$

$$
=0,84 \pm 0,07
$$

Hasil analisis ketidaksepahaman dan kesepahaman masalah terkait obat antara dokter dan apoteker masing-masing disajikan pada Tabel 4 dan 5.

\section{Pembahasan}

Pada penelitian ini, obat yang diresepkan banyak karena tidak hanya untuk indikasi diabetes mellitus tetapi juga untuk komorbidnya, yaitu kardiovaskular, gangguan koagulasi dan neuropati. Pasien dengan multiple komorbid seringkali mengalami polifarmasi yang dapat menyebabkan terjadinya MTO. MTO yang umumnya muncul antara lain, pemilihan obat, penentuan dosis dan kemungkinan interaksi obat [5].

Jumlah obat yang diresepkan untuk pasien diabetes mellitus di apotek tempat penelitian lebih

Tabel 1. Karakteristik demografi pasien

\begin{tabular}{lll}
\hline & Frekuensi & Persentase (\%) \\
\hline Usia & & \\
- <40 tahun & $5 / 102$ & 4,90 \\
- $40-60$ tahun & $53 / 102$ & 51,96 \\
- > 60 tahun & $44 / 102$ & 43,14 \\
\hline Jenis kelamin & & \\
- Perempuan & $45 / 102$ & 44,12 \\
- Laki-laki & $57 / 102$ & 55,88 \\
\hline Komorbid & & \\
- Kardiovaskular & $54 / 102$ & 52,94 \\
- Gangguan koagulasi & $18 / 102$ & 17,65 \\
- Neuropati & $16 / 102$ & 15,69 \\
\hline
\end{tabular}


Table 2. Frekuensi obat atau golongan obat yang diresepkan kepada pasien

\begin{tabular}{lll}
\hline Nama obat & Frekuensi & Persentase (\%) \\
\hline Antidiabetik: & & \\
Insulin & 92 & 19,7 \\
Metformin & 45 & 9,6 \\
Sulfonilurea & 32 & 6,8 \\
Pioglitazon & 21 & 4,5 \\
Akarbose & 13 & 2,8 \\
Antihipertensi: & & \\
Antagonis kalsium & 30 & 6,4 \\
Antagonis reseptor angiotensin II & 28 & 6,0 \\
Penghambat ACE & 18 & 3,8 \\
Bisoprolol & 15 & 3,2 \\
Furosemid & 3 & 0,6 \\
Isosorbid dinitrat & 2 & 0,4 \\
Metildopa & 2 & 0,4 \\
Digoksin & 1 & 0,2 \\
Hidroklorotiazid & 1 & 0,2 \\
Lain-lain: & & \\
Vitamin neurotropik dan asamfolat & 59 & 12,6 \\
AINS dan parasetamol & 25 & 5,3 \\
Aspirin dan klopidogrel & 18 & 3,8 \\
Gabapentin dan amitriptilin & 16 & 3,4 \\
Antasida, ranitidin, omeprazol, lansoprazol & 10 & 2,1 \\
Amoksisilin-klavulanat, sefadroksil, siprofloksasin & 10 & 2,1 \\
Erdostein, sirup ekspektoran & 7 & 1,5 \\
Alopurinol & 5 & 1,1 \\
Setirizin & 4 & 0,9 \\
Fenofibrat dan simvastatin & 3 & 0,6 \\
Alprazolam & 2 & 0,4 \\
Tiamazol, tamsulosin, laxadin, asam traneksamat & $4(@ 1)$ & 0,9 \\
\hline Keterangan: ACE, angiotensin converting enzyme; AINS, antiinflamasi non steroid & \\
$\quad$ Berdasarkan evaluasi terhadap 102 resep; apoteker mengidentifikasi masalah terkait obat pada 23 resep. & \\
& & \\
& &
\end{tabular}

Tabel 3. Penentuan masalah terkait obat oleh dokter-apoteker

\begin{tabular}{lllll}
\hline & & Dokter & \multicolumn{2}{c}{ Total } \\
\cline { 3 - 4 } & & Ya & Tidak & \\
\hline Apoteker & Ya & 18 & 5 & 23 \\
& Tidak & 0 & 79 & 79 \\
\hline Total & 18 & 84 & 102 \\
\hline
\end{tabular}

sedikit (2-10; rata-rata 4,6 obat obat per pasien) daripada di primary care di Wisconsin $(11 \%$ pasien yang memperoleh $0-4$ obat; $34 \%$ pasien yang memperoleh 5-9 obat; $56 \%$ pasien yang memperoleh $\geq 10$ obat) [6]. Pada penelitian ini hanya dijumpai 23 MTO pada 102 pasien diabetes
(0,2 MTO per pasien), lebih kecil daripada kejadian MTO pada penelitian Huri $(1,94 \pm 1,10$ MTO per pasien). Ada 18 MTO yang dokter juga menyetujui dan akhirnya memperbaiki peresepan, yaitu: i.) penggunaan asam folat untuk indikasi hiperhomosisteinemia, belum cukup bukti pene- 
Tabel 4. Ketidaksepahaman masalah terkait obat antara dokter dan apoteker

\begin{tabular}{|c|c|}
\hline \multicolumn{2}{|c|}{ Analisis masalah terkait obat } \\
\hline Oleh Apoteker & Oleh Dokter \\
\hline $\begin{array}{l}\text { 1. Pasien berusia } 70 \text { tahun berisiko mengalami } \\
\text { hipoglikemia pada pemberian glibenklamid. }\end{array}$ & $\begin{array}{l}\text { Bukan masalah terkait obat karena pasien tidak } \\
\text { menderita gangguan fungsi ginjal. }\end{array}$ \\
\hline $\begin{array}{l}\text { 2. Penggunaan metformin potensial memperburuk } \\
\text { gangguan saluran pencernaan pada pasien yang } \\
\text { menderita nyeri perut. }\end{array}$ & $\begin{array}{l}\text { Bukan masalah terkait obat karena nyeri perut } \\
\text { disebabkan oleh gastroenteritis, bukan karena } \\
\text { penggunaan metformin. }\end{array}$ \\
\hline $\begin{array}{l}\text { 3. Pasien tidak mendapat obat untuk mengatasi } \\
\text { mual. }\end{array}$ & $\begin{array}{l}\text { Bukan masalah terkait obat karena keluhan mual } \\
\text { tidak mengganggu aktivitas pasien. }\end{array}$ \\
\hline $\begin{array}{l}\text { 4. Dosis insulin perlu ditingkatkan dari } 3 \text { x } 10 \text { unit } \\
\text { menjadi } 3 \times 12 \text { unit. Gula darah } 2 \text { jam post } \\
\text { prandial pasien pada saat kontrol adalah } 130 \\
\text { mg/dL. }\end{array}$ & $\begin{array}{l}\text { Bukan masalah terkait obat karena menurut dokter } \\
\text { pasien memiliki risiko mengalami hipoglikemia jika } \\
\text { melihat kadar gula darah pasien saat itu. }\end{array}$ \\
\hline $\begin{array}{l}\text { 5. Kadar gula darah pasien tidak terkontrol dengan } \\
\text { pemberian kombinasi obat antidiabetik. Hasil } \\
\text { pemeriksaan gula darah acak }=439 \mathrm{mg} / \mathrm{dL} \text {. }\end{array}$ & $\begin{array}{l}\text { Bukan masalah terkait obat karena ada } \\
\text { kemungkinan pasien tidak patuh mengkonsumsi } \\
\text { obat. }\end{array}$ \\
\hline
\end{tabular}

Tabel 5. Kesepahaman masalah terkait obat antara dokter dan apoteker

\begin{tabular}{ll}
\hline Masalah terkait obat & Alasan \\
\hline Waktu pemberian amitriptilin tidak tepat & $\begin{array}{l}\text { Amitriptilin dapat menyebabkan rasa lelah dan mengantuk } \\
\text { (efek samping obat), oleh karena itu diberikan sebelum tidur. }\end{array}$ \\
Penggunaan asam folat & $\begin{array}{l}\text { Belum cukup bukti yang mendukung penggunaan asam folat } \\
\text { (koenzim dalam metabolism homosistein) dalam } \\
\text { memperlambat progresi penyakit diabetic nefropati, penyakit }\end{array}$ \\
& $\begin{array}{l}\text { kardiovaskuler maupun mencegah progresi resistensi menjadi } \\
\text { DM tipe 2. }\end{array}$ \\
$\begin{array}{l}\text { Peresepan aspirin untuk mengatasi nyeri } \\
\text { di kaki }\end{array}$ & $\begin{array}{l}\text { Aspirin merupakan terapi yang efektif untuk mengatasi gejala } \\
\text { nyeri yang disebabkan oleh Peripheral Arterial Disease (PAD) }\end{array}$ \\
$\begin{array}{l}\text { Penggantian kaptopril dengan obat } \\
\text { antihipertensi lain }\end{array}$ & $\begin{array}{l}\text { Pasien memerlukan kombinasi obat antihipertensi karena } \\
\text { tekanan darah pasien belum terkontrol (150/100 mmHg) }\end{array}$ \\
\hline
\end{tabular}

litian yang mendukung efektivitasnya; ii.) potensi reaksi obat yang tidak dikehendaki (ROTD) mengantuk pada penggunaan amitriptilin di siang hari; iii. ada indikasi nyeri yang belum diterapi; iv. pemberian obat antihipertensi yang bersifat sinergis belum diresepkan. Hal ini berbeda dengan MTO terbanyak pada penelitian Huri, yaitu: i. potensial interaksi obat karena simvastatin dan amlodipin, keduanya merupakan substrat CYP3A4; ii. penentuan dosis simvastatin yang kurang tepat (10\% pasien mendapat dosis tinggi simvasatin bersama dengan amlodipin); iii. obat tidak diminum $(17,6 \%$ pasien tidak patuh minum obat); dan iv. obat yang bersifat sinergis tidak diresepkan [7]. Huri pada penelitiannya menyebutkan peresepan obat antihipertensi tidak berkaitan dengan terjadinya MTO pada pasien diabetes dengan dislipidemia $(p=0,465)$. Resep pasien diabetes mellitus dengan penyakit komorbid berkaitan dengan banyaknya obat yang diresepkan yang berpotensi menyebabkan terjadinya polifarmasi. Polifarmasi berkaitan dengan kepatuhan minum obat yang rendah, serta kemungkinan interaksi obat dan efek samping obat [7].

Tingkat kesepahaman antara dokter dan apoteker pada penelitian ini sangat baik $(\kappa=0,84$, 
95\% CI 0,77-0,91). Pada penelitian ini dokter tidak setuju terhadap MTO terkait gejala penyakit pasien dan kepatuhan pasien, yang diidentifikasi oleh apoteker. Pada PALMERA study apoteker berkolaborasi dengan dokter dalam pemantauan efektivitas obat anti hipertensi di komunitas; tingkat kesepahaman hasil pengukuran tekanan darah pasien antara dokter dan apoteker rendah $(\kappa=0,396)[8]$.

Pada penelitian ini dokter setuju terhadap MTO terkait efektivitas pengobatan yang berbasis bukti dan farmakokinetika obat, yang diidentifikasi oleh apoteker. Hasil survei persepsi dan harapan dokter menunjukkan bahwa harapan dokter terhadap apoteker adalah untuk mengidentifikasi medication error, dan mengedukasi pasien tentang penggunaan obat yang aman dan benar, pelaporan alergi atau interaksi obat, dan sebagai sumber informasi $[9,10]$; hasil survei yang dilakukan Liu melaporkan bahwa prediktor keberhasilan kolaborasi adalah interaksi profesional dan kepercayaan satu sama lain (trustworthiness), bukan spesifikasi peran [11].

\section{Kesimpulan dan Saran}

Hasil analisa menunjukkan tingkat kesepahaman ( $\kappa)$ antara dokter dan apoteker sebesar 0,84 (sangat baik). Kesepahaman antara dokter dan apoteker mengenai masalah terkait obat cukup tinggi yaitu sebesar 95\%; ketidaksepahaman terutama terkait pertimbangan klinis penggunaan obat dan kepatuhan pasien, oleh karena itu apoteker perlu meningkatkan pengetahuan agar dapat berkontribusi dalam kolaborasi tersebut.

\section{Ucapan terima kasih}

Ucapan terima kasih yang sebesar-besarnya kepada dr. Putu Arya Nugraha, Sp.PD. yang telah bersedia bekerja sama dalam penelitian ini. Ucapan terima kasih juga penulis ucapkan kepada Apotek Kimia Farma Singaraja dan apotek rawat jalan RSUD Kabupaten Buleleng atas dukungan fasilitas dan tempat selama tahap pengambilan data penelitian.

\section{Daftar pustaka}

1. Kementerian Kesehatan. Peraturan Menteri Kesehatan Republik Indonesia Nomor 35 Tahun 2014 tentang Standar Pelayanan Kefarmasian di Apotek.

2. Hammond RW, Schwartz AH, Campbell MJ, Remington TL, Chuch S, Blair MM, Vassey AM, Rospond RM, Herner SJ, Webb CE. ACCP position statement: collaborative drug therapy management by pharmacists. Pharmacotherapy. 2003;23(9):1210-25.

3. Granas AG, Berg C, Hjellvik V, Haukereid C, Kronstad A, Blix HS, Killhovd B, Viktil KK, Horn AM. Evaluating categorisation and clinical relevance of drug-related problems in medication reviews. Pharm World Sci. 2010;32:394-403.

4. Field A. Discovering statistics using SPSS. $3^{\text {rd }}$ ed. London: SAGE Publications Ltd; 2009.

5. Huri HZ, Fun Wee. Drug-related problems in type 2 diabetes patients with hypertension: a crosssectional restropective study. BMC Endocrine Disorders. 2013; 13:2.

6. Freund J, Meiman J, Kraus C. Using electronic medical record data to characterize the level of medication use by age-groups in a network of primary care clinics. J Prim Care Community Health. 2013;4(4):286-93.

7. Huri HZ, Ling LC. Drug-related problems in type 2 diabetes mellitus patients with dyslipidemia. $B M C$ Public Health. 2013;13:1192-205.

8. Sendra-Lillo J, Sabater-Hernández D, Sendra-Ortolá A, Martínez-Martínez F. Agreement between community pharmacy, physician's office, and home blood pressure measurement methods: the palmera study. Am J Hypertens. 2012;25(3):290-6.

9. Alkhateeb FM, Unni E, Latif D, Shawaqfeh MS, Al-Rousan RM.Physician attitudes toward collaborative agreements with pharmacists and their expectations of community pharmacists' respon- 
sibilities in West Virginia. J Am Pharm Assoc. 2009;49(6):797-800.

10. Owens C, Baergen R, Cady P. Multistate survey of primary care physician and midlevel provider attitudes toward community pharmacists. $J \mathrm{Am}$
Pharm Assoc. 2009;49(4):538-43.

11. Liu Y, Doucette WR, Farris KB. Examining the development of pharmacist-physician collaboration over 3 months. Res Social Adm Pharm. 2010;6(4):324-33. 